\title{
A Tribute to Carlos Augusto Angel Maya
}

\author{
Ana Patricia Noguera de Echeverri ${ }^{1}$ and Ricardo Rozzi ${ }^{2}$
}

During the night of 11 September 2010, at age seventy-eight, Colombian philosopher Carlos Augusto Angel Maya passed away in Cali. This "maestro de maestros" of Latin American environmental thought was closer to life, to Ataraxia (the title of one of his final works), to the enjoyment of life in life, than to the notion of development, or sustainable development. Maya opened the possibility of environmental thought for Colombia and Latin America, stemming from the complexity of the webs of life, as explored in his Web of Life, published in 1994, four years before Fritjof Capra's The Web of Life. Both Maya and Capra would show that life in its very fabric is complexity.

Having been woven for millions of years, today the dense web of life demands from global society a profound transformation of all symbols, of the entire framework, of all stories, teleologies, foundations, and images of the metaphysical culture that the prophetic poet Hölderlin defined in the early nineteenth century-at the height of the Enlightenment, but also of restless Romanticism, skeptic of the messianic promises of modern rationality - as "a sly race that thinks it knows what it is doing."

Mainstream approaches to global climate change and the socio-ecological crisis focus on novel ways of understanding and using nature. Maya, philosopher-poet of life, invites us to look backward to ancient, traditional forms of conceiving and inhabiting the world. In order to heal the relationship between society and nature, we need to undo the path that has taken modern global thought away from nature into abstractions of numbers and ideas that have lost all connection with the physical world. Maya's school of thought guides students in this deconstruction of the abstract path of thought, enabling them to arrive at one of the original, most fertile sources, of Western thought: the pre-Socratics.

The pre-Socratics "were not polluted by the infection and spread of the disease of logos," which put a veil between nature and the dominant current of thought in Western civilization. With modernity, this veil was imposed around the world through a process of colonial conquering and suppression of local forms of knowledge rooted in local ecological and cultural realities. With the Ionians, Maya explores the unity between the human and the other-than-human. These pre-Socratics offer Western science insights into the unity between energy and matter, and spirit and nature. The whole body matters - not only a disembodied brain - if we want to

\footnotetext{
${ }^{1}$ Department of Human Sciences and the Institute of Environmental Studies (IDEA), the National University of Colombia, Campus Manizales; email: panoguera@gmail.com. Noguera is the co-founder, an investigator, and the coordinator of the Group of Environmental Thinking "Augusto Angel Maya."

2 Department of Philosophy and Religion Studies, University of North Texas, Denton, TX 7620309290, and Institute of Ecology and Biodiversity, Universidad de Magallanes, Chile; email: rozzi@unt. edu. Rozzi is the representative for South America for the International Society of Environmental Ethics.
} 
recover the cognitive and ethical connection with nature. Maya's philosophical turn resonates with Aldo Leopold's ecological-ethical call to listen to the wolf that lives in the mountains and in ourselves, and which has been forgotten by modern society. Continuing the life of Maya's thought, the work of the Colombian philosopher and the U.S. ecologist, Leopold, will be discussed in the context of a counterpoint between South and North American perspectives on environmental philosophy at the Fifth Conference on Latin/Inter-American Environmental Thought in Magallanes, Chile, on 16 to 19 March 2012.

Maya was also a builder of institutional spaces for environmental philosophy in Latin America. In 1987, at the National University of Colombia, he opened the window to anomalous thinking - without secure foundations, apodictic bases, teleologies, or universal axioms; a philosophical thought that will remain in the margins of the philosophy of subject and object, where reason is the starting point, only path, and port of entry. This window places modernity's most precious creations - reason, science, technology, progress and development - in jeopardy. One of Maya's famous statements resonates beautifully with the opening phrase of Edmund Husserl's lecture in Vienna in 1935: "The crisis of the sciences is not a crisis of method, but one of meaning." "The environmental crisis," said Maya in his book The Environmental Fragility of Culture, published in 1995, "is not a crisis of natural resources, but one of civilization."

This environmental crisis began to undermine the most genuine and untouchable philosophical principles of modern philosophy. For this reason, Maya rigorously explored the origins of the persistent division in Western culture between society and nature, culture and nature, and reason and nature. This work was laboriously carried out in the book series Reason of Life (1997-2003), which culminated with two great works that today are mandatory reading in the burgeoning environmental philosophy-ethics-aesthetics community: The Return of Icarus and The Enigma of Parmenides. In these beautifully written works, Maya left a legacy of infinite value for the community of environmental thought in Colombia, in Latin America, and throughout the world. The Return of Icarus invites philosophy to return to Earth, to an immanent philosophy. As a contribution to this endeavor, the Center for Environmental Philosophy at the University of North Texas, in collaboration with the University of Magallanes and the University of Colombia, is preparing an annotated translation for the English-speaking world.

In his work that is his life, and his life that is his work, Maya places the environmental crisis in terms of the ecosystem-culture relationship, a model that resignifies, redefines, and reconfigures the environment as an emergence of that dense, complex relationship. Since nineteenth-century ecology, the environment has been reduced to nature without man, to an ecosystem outside the human socio-cultural system. Maya's vast proposal places the environmental crisis within the socio-culturalecosystem relationship, and proposes the possibility of an environmental society in which environmental thought - as a way of thinking about how we inhabit this Earth - would be the foundation of politics, economics, and the symbolic world. 